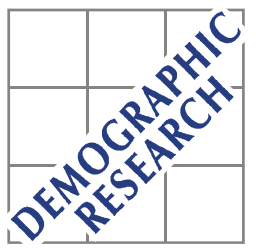

Demographic Research a free, expedited, online journal of peer-reviewed research and commentary in the population sciences published by the Max Planck Institute for Demographic Research Konrad-Zuse Str. 1, D-18057 Rostock · GERMANY www.demographic-research.org

DEMOGRAPHIC RESEARCH

SPECIAL COLLECTION 3, ARTICLE 4

PUBLISHED 17 APRIL 2004, PAGES 87-116

www.demographic-research.org/special/3/4/

DOI: 10.4054/DemRes.2004.S3.4

Research Article

\title{
Reproduction at the Margins: Migration and Legitimacy in the New Europe
}

\section{Caroline H. Bledsoe}

This special collection is in honor of Jan M. Hoem on his $65^{\text {th }}$ birthday. The authors presented their papers at a working party at the Max Planck Institute for Demographic Research in Rostock, Germany in April 2004. The collection is edited by Gunnar Andersson and Gerda Neyer.

(C) 2004 Max-Planck-Gesellschaft. 


\section{Table of Contents}

1 Introduction $\quad 88$

$2 \quad$ Challenges in studying immigrant populations in 89 the new Europe

$3 \quad$ Why anthropology? 92

$3.1 \quad$ Culturally defined legitimacy 93

3.2 Movement and legitimacy in the new global order 94

3.3 Agency, legitimacy, and immigrant dynamics 95

$4 \quad$ Reproduction and legitimacy in the margins of the 98 new Europe

5 Conclusion 106

6 Acknowledgements 107

$\begin{array}{ll}\text { Notes } & 108\end{array}$

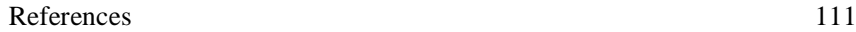


Demographic Research - Special Collection 3: Article 4

-- Contemporary Research on European Fertility: Perspectives and Developments --

Research Article

\title{
Reproduction at the Margins: Migration and Legitimacy in the New Europe
}

\author{
Caroline H. Bledsoe ${ }^{1}$
}

\begin{abstract}
One of the most compelling demographic questions in contemporary Europe has been whether immigrant populations will bring their youthful age pyramids to help support Europe's subfertile, aging populations. But how do immigrants envision their own reproductive life trajectories across vast, ambiguous political boundaries whose seismic shifts can threaten their security? This paper reviews some recent literature from demography, anthropology, and the media as well as several case studies to suggest that for immigrant families at the political margins of Europe, especially those from developing countries, the most pressing fertility question is not numbers of children. It is instead the legitimacy that children may provide in their families' efforts to gain work, social security, and rights to settle. This implies that the reproductive practices adopted by immigrants in Europe may derive less from traditions in their home countries than from efforts to adapt to new rules of "belonging" in Europe. Indeed, what seem very striking in the light of conspicuously low and increasingly non-marital fertility in mainstream Western Europe are the increasing demands placed on immigrants to pursue legitimacy in their reproductive lives. The paper concludes that levels of fertility among immigrants are unlikely to assimilate to the national norms until people's status becomes more secure. Finally, just as we can no longer rest on conventional notions of reproductive practices in the developing world, it is increasingly impossible to draw general conclusions about fertility in Europe without keeping the developing world in view.
\end{abstract}

1 Dept. of Anthropology, 1810 Hinman St., Northwestern University, Evanston, IL. 60208-1310

USA. Fax: 1847 467-1778; E-mail: cbledsoe@ northwestern.edu 
Demographic Research - Special Collection 3: Article 4

-- Contemporary Research on European Fertility: Perspectives and Developments --

\section{Introduction}

Contemporary Europe has witnessed some of the most remarkable population trends in history. The one that has dominated demographic attention has been a drop in fertility to levels well below replacement. Drawing nearly as much attention has been a loosening of marital bonds, producing what Lesthaeghe and van de Kaa (1986) termed the "second demographic transition": increasing rates of non-marital union and divorce, with concomitant increases in rates of children's residence in households with a single parent or in households that include a step-parent (Note 1). Another recent trend, however, has just begun to attract substantial demographic notice, though of late it has taken center stage in the popular media: the rise in immigration to the European Union from the Third World and Eastern Europe (Note 2).

If there have been few demographic studies of immigrants, compared to the other two trends, even less is known about immigrants' fertility. There have been debates on whether developing country populations will bring their youthful age pyramids to help support Europe's subfertile, aging "rectangular" populations. But the frame of reference is still "native" Europe. How do immigrants from outside the E.U., and especially those in marginal circumstances (i.e., not established residents from wealthy countries) envision their own reproductive life trajectories across the vast, ambiguous political boundaries whose seismic shifts can threaten their security?

In developing countries, families look to children for political and economic security. They need help with upkeep of the farm and the house, and support when they are unemployed or need medical care. For all these purposes, they seek assistance from children regardless of how far from home the children have gone, whether to a nearby village or to Paris or New York. How and under what circumstances one bears a child may affect the welfare of the rest of the family, and hence their access to employment, education, medical care, and political protection. The point to make about reproduction, and it is both obvious and yet paradoxical: adults never fully reproduce themselves. Children have some of the same social and economic characteristics as their parents -but not all. They are born into different times and, possibly, places than their parents, and they have different kin configurations. They may also have different nationalities. Through connection to a child, an adult gains more attributes than his/her own: attributes that might be used to make additional claims on society. In an increasingly "connected" world, children may offer new pathways for their families' mobility and the security it can bring. Hence, the most compelling starting point for studying immigrant views of reproduction is less the number of children immigrants produce than the social legitimacy that children might offer them (Note 3).

Using library and internet sources, I review a range of anthropological and demographic works and compile several case studies to address some theoretical and 
empirical issues of reproduction among immigrants in Europe. I focus on immigrants in more marginal statuses because doing so may shed explanatory light on quantitative fertility trends among immigrants and longstanding citizens alike. It also captures some unexplored facets of the value of children in this era of rapid globalization. What emerges clearly is that immigrants at the margins of political legitimacy conduct their reproductive lives as they do so much else, with an eye to how these acts will affect their security. Whereas much of my previous work in Africa found that a woman's efforts to bear children for a worthy husband and his family to solidify her wifely legitimacy make reproduction a highly political matter (Note 4), I now consider the same for bearing children as a link to a specific nation or state. The question is which state these children come to be linked to, and how the rapid flux in rules governing affiliation with different states may affect immigrants' reproductive strategies. Because the potential topics are so broad, most of my examples focus on circumstances of time and place of children's births.

\section{Challenges in studying immigrant populations in the new Europe}

Taking on any one topic in the demography of contemporary Europe is no small challenge. The European Union in May, 2004 will have twenty-five member countries, a group with extraordinarily dissimilar histories and policies governing citizenship, work, and welfare. Until the collapse of the Soviet Union in the early 1990's and its centralized control over much of central and eastern Europe, even Germany belonged to two poles of the political divide whose differences were so vast that, if plotted geographically, might have represented opposite sides of the globe. As well there is a panoply of E.U. economic and political organizations and agreements -- the Economic and Monetary Union, the European Free Trade Agreement, the Club of Rome, the Treaty of Amsterdam, and so on. Wealthy countries or countries with historical agreements with other countries already in place tend to be most selective about the pieces they want to sign onto. For example, Norway, with its oil riches, has seen little reason to become a full E.U. member, although it did sign the Schengen Agreement governing free passage of legitimately documented persons. Countries such as the Czech Republic and Turkey, however, which had much to gain by joining the E.U., were held at arm's length until very recently. And the definition of the E.U. changes almost weekly as new cultural units, political boundaries, and institutions emerge, and as the rules governing access to entry, work, and citizenship are rewritten.

Just as there are many kinds of countries, policies, and institutions within the E.U., there are numerous kinds of individuals who live or work in them. A typology based on shades of legitimacy and permanence might include: 
(1) legally recognized citizens with full rights to vote in and derive benefits from an E.U. country;

(2) citizens of "candidate" countries that are not yet officially part of the E.U. but that are slated to be acceded;

(3) people with various kinds of recognized rights of residence, work, education, or asylum, or through a sanctioned tie to an E.U. citizen such as a spouse, a parent or a child;

(4) refugees seeking asylum from an oppressive regime whose cases are pending;

(5) people who live or travel in the illicit shadows of the E.U.

The question of immigrants is of particular importance as the boundaries of the European Union expand. It is still understudied, however, in demography. One reason is the incomplete nature of quantitative data sources. Partly this stems from disagreement over who, exactly, an immigrant is. It also reflects the fact that many European nations have refused to collect census data on questions like religion or ethnicity, given their stark memories of Nazi Europe's treatment of Jews. Further, many immigrants lead invisible lives, as my typology above implied. Some people arrive in quite straightforward ways, as part of family reunification packages or having desired skills that earn them immediate rights to residence or citizenship. There is temporal variation as well. Some people settle permanently; others come for brief stints -- to attend a funeral, to visit kin, or to earn money for marriage, a plot of land, school fees, or a relative's surgery (Note 5). Shading toward the "less legal" are people who obtained permits for seasonal work but overstayed their legal welcome, frequently with the collusion of their employers. More extreme acts of desperation are reflected in the cases of young men racing through the Eurotunnel, clinging to the undersides of railroad cars, enduring treks across the Sahara, or negotiating the treacherous Straits of Gibraltar. For young women, there are grim crossings and voyages as well, often as victims of international smugglers who traffic in women and girls. As for children, one could point to the hundreds of children sent by their families from war-ravaged Somalia by one-way air tickets, with no one to meet them and no traceable identity (The Scotsman - International, Jan. 23, 2003). All social identities are multiple and fluid. But as requirements for mobility tighten, immigrants - and those who are said to look like immigrants - find it increasingly difficult to disentangle themselves from the label, regardless of how many generations elapse. Some have speculated that the label "immigrant" may become a perpetual category, a kind of social class in which families can become locked (de Genova, 2002; Neveu, 2000).

In sum, the welcome that some migrants receive should not be allowed to overshadow the plights of many others who must hide beneath the horizon of visibility 
of formal institutions (Note 6). Given such precarious rights to housing, residence, and work, it should not be surprising that trying to pin down the identities of people who are trying equally hard to obfuscate them is next to impossible.

Clearly, the term "immigrant" covers a broad front of overlapping, ambiguous categories. Clearly as well, the unprecedented upsurge in movements of people, communications, and citizenship demands not simply calculating numbers of people. It also demands a combined social, cultural and legal lens. As I found in my 1982-93 Sierra Leone study of child fosterage (1990), the assumption that the people are subject solely to policies on health, education, and employment in their places of origin is increasingly untenable (Note 7). Each country has different criteria for granting (or withholding) citizenship or rights to live or work. Variants may include rights of "blood" descent from an appropriately recognized parent or ancestor, versus rights of "soil": citizenship by birth or naturalization. And just as everyone who lives within a country's territorial boundary is not necessarily a countable citizen, people living outside a nation's boundaries may figure centrally in the lives of those within. What does matter a great deal in the E.U. is a set of rules that all member states have been expected to sign: the Schengen Agreement. This agreement, originally signed in Schengen, Luxembourg in 1985 by Germany, France, Netherlands, Luxembourg and Belgium, eased border controls among the signatories, mandating free passage across national borders for citizens of the various member states. However, it also effectively set the conditions of marginality for those who could not qualify as legitimate citizens or residents. Indeed, subsequent agreements such as the Amsterdam Treaty (1997) have effectively sought to place even tighter restrictions on the movement of persons through attempting to unite efforts at external border control, asylum and immigration, and a policing system through a vast shared information system, including photos and fingerprints.

As for why there is comparatively little published material on the reproduction of children in larger migration schemes in Europe, I have no ready explanation. My best guess is that Western disciplines have simply placed the two topics - migration and fertility - into different analytical frames in our own cultural thinking. Migration is often paired with employment and even with marriage. Fertility goes "naturally" with marriage and with mortality. But migration and fertility somehow seem to occupy wholly different categories in our analyses, though there is every reason to think that this is a lively association in the minds of those whose demographically relevant events are counted. Given the paucity of studies that address the dynamics of immigrant reproduction in the emergent Europe, one can only point to promising directions from a few suggestive case studies from Western Europe: a collection that cannot possibly hope to be representative of a spectrum of countries, although all the authors allude to 
broader quantitative patterns. I also draw on circumstantial logics from anthropological and demographic writings.

This paper, then, rests on three caveats. First, describing quantitative levels and trends in either immigration or fertility is beyond the present scope of the focus on social dynamics. The findings do seem quite relevant to understanding fertility numbers, however, so I return briefly to the question at the end. Secondly, beyond the scope as well is any attempt to decide whether migration is overall a bonus or a detriment to the societies that either send or receive migrants. These are enormously complicated issues, and the fact that countries are so selective in who they admit makes the matter all the more complex. Of interest, rather, is how people at the margins of legitimacy try to structure their reproductive lives within the shifting boundaries and policies of the E.U. Looking at people in marginal situations helps to shed light on the value of children arising from new patterns of globalization, whether we consider reproduction among immigrants or among longstanding citizens. Finally, although I single out two individual cases that have drawn international attention, I focus less on the sensationalistic reports of immigrant dilemmas that capture public attention perilous entries, brothels, sweat shops, refugee camps - than more routine adaptations to life at the margins, though many would argue that such specters are central to the concerns of immigrants to the E.U.

\section{Why anthropology?}

A discipline like anthropology that has built its business on studying remote, exotic locales might seem an unlikely vehicle for studying immigration and fertility in contemporary Europe (Note 8). But anthropology's classic emphasis on culture (by which I imply "meaning") as well as legitimacy and social agency (Note 9), together with its newer interests in globalism and citizenship, suggest some promising synergies between demography and anthropology.

There is a rich tradition of ethnography on Europe and its long cultural experience with population movement for commerce, marriage, war, and the spread of religious and secular instruction (Note 10). Anthropologists also described patterns wherein children were sent out when a family's land holdings were threatened by too many heirs, for service, to religious orders, or to learn a trade. Certainly the history of the U.S. could not be told without recognizing the tens of thousands of European immigrants who came every year, as late as the 1950s. But ethnographies of the past were dominated by descriptions of isolated, traditional peasants. It was largely with the work of scholars such as Eric Wolf (1982), Raymond Smith (1956), Edward Said (1978), and Immanuel Wallerstein (1974) that key attention was drawn to the role of larger state and 
international schemes in peasant life (Note 11), and to the fact that the migration of young people to cities often came at a steep economic and psychological cost to their homelands. Brettell's studies of a village in northern Portugal $(1986,1995)$ have reported on the impact of two and a half centuries of emigration on the lives of family members, both those who leave and those who remain behind. Pierre Bourdieu's study of his natal village in rural France, Bal des Célebataires (2002b) depicted the plight of aging peasant bachelors when young women left for the city, finding it unappealing to marry men whose future was shackled to a small plot of inherited land. And in a controversial work from rural Western Ireland, Scheper-Hughes (Saints, Scholars, and Schizophrenics, 1979) pointed to outmigration as a major cause of mental illness among last-born males in the wake of government efforts to force small farmers off the land. Caught in the squeeze as the impoverished country struggled for viability in the larger European Economic Community scheme, Scheper-Hughes argues, families raised girls and older sons with a recognition that they would likely emigrate but tried to ensure a successor for the farm by instilling the lastborn son with an extreme sense of incompetence. Whether these "leftover" sons became obviously deviant schizophrenics or eccentric but harmless "saints," they remained bound pathologically close to home and land.

In the space of little more than a generation, of course, Western Europe has been transformed utterly, no longer producing people for export but becoming a magnet, whether for immigrants fleeing from a repressive regime or simply seeking a better life in a distant land. With fertility so low and E.U. economies thriving, it is the cultural dynamics of Europe as a potentially importing epicenter of persons, together with the new rule structures that are being put in place to govern these movements, that is so engrossing.

\subsection{Culturally defined legitimacy}

For investigating reproduction in the margins of this vacillating mix of countries, policies, and people, a concept that holds great explanatory weight is legitimacy. Legitimacy that falls short of ideal standards has long preoccupied political philosophers, literary critics, historians, and sociologists. But it has gained particular currency in anthropology, where it has been applied to vast domains of research, whether on ethnicity, nationality, or position in a network of economic exchange. Applied to the family, the relevant questions have been: who is a legitimate member of a family and how is this legitimacy acquired?

Anthropologist Mary Douglas (1966) argued that humans are profoundly uncomfortable with mingling elements of culturally established categories, and mark 
the boundaries between categories accordingly, with fears of pollution or contamination. Her observation finds an apt example in concerns about legitimacy, especially a properly sanctioned marriage between suitable partners and the proper timing of the arrival of their offspring (for an engaging study of Africa, see Launay, 1995). In most European societies of the past, but also some contemporary ones, births that occurred before marriage were regarded as transgressions of appropriate cultural boundaries: uncomfortable breaches of established temporal boundaries that defined marital categories. Indeed, nowhere in the anthropological, sociological, or historical canon have the cultural emphases on legitimacy and the social strategies they set in motion, whether to avoid accusations of illegitimacy or to use them against rivals, been more visible than in what has sometimes been called the "honor/shame" cultural complex of Mediterranean/Southern Europe (see, e.g., Péristiany, 1966; Gilmore, 1987). In this set of ideas, familial reputation rested on the sexual virtue of young women. The most damning evidence of a woman's immorality was the pre-marital appearance of a child, especially if there was no credible husband candidate in sight. To ensure that the sexual relations that produced a child occurred within the bounds of an honorable union, people calculated retrospectively a highly specific temporal sequence: a sanctioned conjugal union followed by a pregnancy (see Laslett 1980 for a classic work on variations on this theme in historical Europe). In extreme cases, families could lose everything by a female member's immorality: Claims to land, livestock, appropriate marriage partners, money, jewels, titles. Given the enormous economic and symbolic payload that rested on this delicately timed sequence of events - not only the legitimacy of children, but the "honor" of men, the "shame" of women, and also, in the case of royalty, entire political states (Note 12) - it should hardly be surprising that men and female elders tried to safeguard female virtue, by threat or force, if necessary.

\subsection{Movement and legitimacy in the new global order}

Until the 1970s, anthropologists' interests in legitimacy were confined to status in small kinship units. Questions centered on births: when children were born relative to the timing of a marriage, who they were born to, and what links they forged between households. Starting in the 1970s, however, scholars across the humanities and social sciences began to take in a bigger picture. Pursuing themes of hybrid identities and displacement in a postcolonial world, they began to explore permutations of legitimacy in the era of what has come to be called globalism. Globalism studies see the most farflung corners of the world as now interlinked and interdependent (Note 13). Studies of globalism in anthropology and other disciplines are complementary to demographic studies in the classic sense of interests in the movement of people, but they are 
concerned as well with the movement of objects, information, and wealth. With information, business, money, and educational offerings now flowing readily across national boundaries, odd disjunctures are opened on a wide global front. American phone companies "outsource" services to India and Pakistan where operators adopt American names and feign American accents in exchange for wages much lower than what American operators would accept. Farm co-ops in rural Bangladesh check the price of grains each day on the Chicago Board of Trade. Mauretanian currency traders, cell phones in hand, stand alongside Senegalese cloth sellers in rural Gambian markets, checking the daily prices of the euro, the dollar, and the pound. Diseases travel readily on jet planes, and even body parts speed through time and geography, detached from their original owners and sold to new ones seeking transplant surgery (Note 14). Scrambling to keep pace with these extraordinary changes, academic journals, books, symposia, fellowships, and prize competitions are springing up, their subject matter replete with everything from tourist art to the political economy of ethnic resistance. Whatever individual anthropologists think of the concept of globalism itself, attaching an after-the-fact chapter on "social change" to a book about a "traditional" society no longer suffices.

If social science scholarship is increasingly about citizenship and about movements of people, information, and money in an unstable world, it is also about the dynamics of marginalization in the global peripheries. Integral to this scholarship is the conviction that social classes now span international locations, and that life at the bottom of social order is led in the international margins. While jet-setting "dot.comers" from Bangalore, India move in social circles with their roommates from Oxford and with Hollywood royalty, the village tradesmen with whom they grew up become increasingly vulnerable to global forces that set their prices and reduce their political communities to "ethnic enclaves." Writing of Britain, Anderson (2000) reports that it is increasingly immigrant women, from places like Poland, Russia, Africa, and the Caribbean, who fill the domestic "caring gap" in British society, taking care of the old, the disabled, and the very young. Many, however, must leave their own children in their own countries with relatives or friends, and with little financial support. And for individuals at the farthest margins of legitimacy, there can be acute costs when national policies are swept aside by new political parties.

\subsection{Agency, legitimacy, and immigrant dynamics}

Many of the examples in globalism studies have a bleak note. So one final development (and my reference again is anthropology), appearing in the 1970s, is important to insert: variously termed "processualist," "strategic," "interactionist," "constructionist," and so 
on. Individuals became recognized as agents capable of sizing up situations and carrying out actions, if not always to maximal economic utility then with intention (e.g., Comaroff and Roberts, 1981; see Bourdieu, 2002a, for a population-relevant selection). Social life became seen as contestations over meaning, wherein people do not mechanically follow the cultural rules their societies appear to lay down but attempt to press claims. One of the most often cited applications of these approaches has been ethnicity and national identity. Whereas ethnic groups previously were regarded as distinct isolates with static customs that demanded compliance, anthropologists have come alive to the idea that ethnic characteristics are fluid and that people may try to claim allegiance to groups that offer the most situational advantage (Barth, 1969).

Aihwa Ong's (2002) analysis of what she calls "flexible citizenship" offers an example. By this she refers to attempts by elite Chinese entrepreneurial managers, technocrats, and business professionals to exploit shifting national rules of affiliation for investment, work, and relocation in a vast international diaspora as they "....seek to evade, deflect, and take advantage of political and economic conditions in different parts of the world" (2002: 174). They set about their international entrepreneurial business across national and continental boundaries, seeking out emerging "loopholes" in various national laws and catching the corners of policies in ways unforeseen by lawmakers. In turn, states respond by continually readjusting their policies. Thus, as Ong observes, "To understand the tactical practices of this diasporan managerial class, we must locate them within and one step ahead of the various regimes of truth and power to which they, as traveling persons, are subject..." (2002: 174).

Although citizenship has been conventionally thought of as based on political rights and participation within a sovereign state, globalization has made economic calculation a major element in diasporan subjects' choice of citizenship, as well as in the ways nation-states redefine immigration laws.... [T]he convergence of Chinese family forms with flexible strategies of capital accumulation enables them to bypass or exploit citizenship rules - whatever the case may be - as they relocate capital and/or family members overseas (2002: 174).

In this insightful example, we see a group whose members are able to exploit their freedom of movement, cobbling together elements of multiple systems in situationally contingent ways. Though they are not poor, these individuals at the margins of one state are trying selectively to activate personal characteristics that give them advantages in another, in ways that are unanticipated by those who create the rules governing various kinds of belonging. In a continuous dialectic, as international managerial elites try to stay ahead of the rules that would hamper their movement in their international business diaspora, they effectively change the rules of the entire system. 
A striking example of attempting to use identity shifting and geographical mobility to situational advantage in recent years has been "asylum shopping." In this practice, individuals seeking political asylum apply, often on the internet, to multiple countries, seeking to match (or construe) their own characteristics and backgrounds with the criteria a particular country is willing to accept. Although E.U. countries are trying to clamp down on such actions, would-be settlers still look for ways to establish new identities or select facets of old ones that might qualify them for asylum in one or another country. A final example comes from an engaging study of traders who travel between Congo and Paris "on the margins of the law." As MacGaffey and Bazenguissa-Ganga (2000) report, many traders from the Congo who seek to do business in Europe yet whose visa applications are denied may borrow the papers of someone with a legitimate French visa or engage in a stepping stone strategy, obtaining the passport of someone from a country whose former colonial master still allows travel to Europe. Until a few years ago, a Congolese could easily borrow an Angolan passport to apply for a visa to Portugal, Belgium, Spain, or Italy, from which point he or she was free, under the Schengen Agreement, to travel by train to the destination country without becoming subject to border controls (ibid.: 98). As border controls have tightened, however, and better ways are found to check identities, ever-more circuitous means of travel are devised (Note 15).

To be sure, individuals who engage in these activities do not have law-breaking as their motive. But they do seek to construe meanings in ways that favor their interests, and exploiting loopholes is one strategy that may be necessary. As Neyer, forthcoming, underscores, creating policies inevitably creates the potential for actions that contravene these policies, whether we call them "unintended consequences" (Note 16) or something else. As states respond, attempting to impose clarity that will in turn allow them to impose restrictions, the results will inevitably have yet more loopholes and ambiguous meanings that people at the margins in turn may try to press (Note 17).

Anthropological studies increasingly attune to social positions that become vulnerable through social policies, tariffs, and currencies as national boundaries shift. Whether one is doing business for giant corporations or seeking safe haven from political upheaval back home, mobility is the key to security in this new world. Anthropologists have also waked up to the realization that with the ease of communications and travel, many of our subjects are showing up on our doorsteps, whether as co-workers, fellow citizens, or family members. In fact, as political economists have established, the lines dividing "them" and "us" were blurred long ago, as colonial governments, missionaries, and traders reached so pervasively into our field sites. The lines blurred as well with our realization that we are as exotic as our distant subjects. Viewing "home" - by which I refer to the contemporary west, whether the U.S. or Europe - as an ethnographic location has become as important as understanding 
Brazil, Indonesia, or the Congo. For all these reasons, much anthropological research has also turned to movement from the former colonies to the heart of the former colonial powers themselves.

\section{Reproduction and legitimacy in the margins of the new Europe}

As in the classic works in Europe, some of the most consuming questions of reproduction continue to surround the margins of legitimacy: timing of birth, rights to land or the goods produced on it, etc. But unlike previous emphases on legitimacy within a family headed by properly married "native" [European] parents, questions today have shifted to wider territorial scales: to legitimacy within countries and even world regions. If children are never replicas of their parents, how might they broker their families' efforts to gain security in the new global dynamics of marginality and legitimacy? Below I examine a few case studies involving national logics that define legitimacy, and some strategies ("unintended consequences," from the perspective of governments) they generate. Most turn on the time and place of what remains a politically charged event - a child's birth - but others concern children's movements. Some are illegal or quasi-legal; others are quite legal, although they are vulnerable to pressures for change.

"Anchor babies" in the United States: I begin with a comparative example from my own country: the phenomenon of the children who have come to be labeled "anchor babies." This term refers to children who, by virtue of their birth on U.S. soil, become the means by which their families stake a future claim on legal U.S. residence.

The right to citizenship by virtue of a U.S. place of birth is inscribed in constitutional law, giving a child all the privileges and responsibilities that citizenship now entails: voting rights when he/she turns 18 (the age of legal majority), vulnerability to the draft; available as well is access to public jobs, welfare, and university scholarships. Equally important in the anchor baby phenomenon is the rule of family reunification, by which a child-citizen, upon reaching age 18, may petition to bring any family members (parents, spouse, children, and unmarried siblings) into the country as legal residents. With citizenship in a wealthy country such as the U.S. at such a global premium, a law guaranteeing citizenship based on a U.S. place of birth, coupled with a law allowing family reunification, and set in a context of geographical contiguity to a much poorer country - all this gives rise to quite predictable birth strategies for some women of Mexican nationality. A number of impoverished pregnant women every year try to reach the U.S. reach the U.S. to give birth by undertaking dangerous crossings that parallel those in Europe: trekking across deserts, entering cargo containers, and 
even crossing dangerous rivers. But the most striking cases may be wealthy Mexican women who cross the border in the most routine manner, not just once but multiple times, for prenatal checks with the physician who they have engaged to deliver them. This they do by using three-day temporary visas available to individuals who can demonstrate financial stability and a residence close to the border. Using another threeday visa, they schedule an induced labor or a caesarean birth, after which they obtain the child's birth certificate and return to Mexico. After 18 years, the now-grown U.S. citizen-child can apply for residence for the rest of the family in the U.S. ("A different kind of Border Cross, " Chicago Tribune, April 30, 2003). In effect, a non-U.S. citizen, through the highly strategic use of just one birth, can eventually transform an entire family into individuals with permanent legitimacy.

Not surprisingly, this effort to take advantage of national laws is beginning to produce calls for reform from many in the mainstream citizenry, especially in the border states, who object that these "anchor" children will swell population growth and take unfair advantage of "real" citizens' benefits. On the other hand, American doctors and hospitals on the U.S. side use this idiosyncratic combination of laws and geography to their own advantage, openly advertising their services to affluent Mexican patients. And the ease with which affluent Mexican women cross the border so easily to give birth to U.S. citizens should not be allowed to obscure the risk to which thousands of impoverished Latinos from the south are exposed when they try to stake a claim in the U.S. by running the border.

"Naturalizing" ancestors in Goa: Countries occasionally grant citizenship to the descendants of their citizens from the colonial past. The tiny state of Goa, a former Portuguese colony on the western coast in India, shows how convoluted the resulting strategies can become, especially when incentives shift so sharply (Note 18).

Under an old law, Goans are eligible for Portuguese citizenship, and hence for full rights E.U. citizenship, if they can document their descent from someone born in the state before 1961: the date when the Indian army seized control of the territory from the Portuguese. Most former Portuguese passport holders had been content to be Goans until 1986, when Portugal joined the E.U. When the "old country" began a "modern makeover," however, many Goans became interested in the possibility of Portuguese citizenship (Note 19) by taking advantage of history. Indian law does not allow dual citizenship, but many Goans are willing to renounce their Indian citizenship to obtain a passport that effectively gives them full rights as citizens in the E.U. (Note 20). So strong is the desire for Portuguese citizenship now that some applicants try to construe their qualifications for Portuguese citizenship by "naturalizing" a pre-1961 Goan-born parent or grandparent posthumously, in the official Goan birth registries, to Portuguese citizenship. Besides altering an ancestor's citizenship, a Goan seeking Portuguese 
citizenship may also try to claim as his ancestor someone who was not an ancestor, or alter an actual ancestor's time or place of birth. The greatest paradox, however, lies in the fact that although many of these naturalized dead ancestors had decisively renounced their Portuguese citizenship by burning their Portuguese passports, some are now being converted to the nationality of the hated colonial master.

As in the U.S. example, this case reveals that birth can have high political stakes. Also parallel to the U.S. example, the fact that Goans who obtain Portuguese citizenship through such means, and especially only now that Portugal is becoming a more affluent country, is coming to be regarded by many "native" Portuguese with chagrin: no longer as an act of generous inclusiveness but a mortifying archaic oversight. But it also demonstrates that neither birth, nor even ancestral disapproval, necessarily determines the affiliation or legitimacy of descendants. Instead, descendants may seek to redefine the meaning of an ancestral birth in the past in ways that will give them political advantages in a changed present.

Irish-born children and their parent-caretakers: Like the U.S., Ireland gives citizenship to anyone born on its soil and is the only European country to do so. But Ireland has gone a step further than the U.S. In 1990, the Fajujonu case established that Irish-born children had the right to the "care, company and parentage" of their parents that is, that the parents had rights to residence in Ireland, as long as they were clearly playing a role in the maintenance of the child. In the rich description by Kómoláfé (2002), Fajujonu, a man from Nigeria, became illegally resident in Ireland when his Irish visa expired in 1981. Although he was vulnerable to deportation, the High Court decided that his two Irish-born children had the right to stay and that he could remain in the country with them. In the unambiguous view of Kómoláfé, the parents "... were able to manipulate the technicalities of the immigration law in Ireland at the time." Indeed, subsequently, there was a significant increase in immigration from Nigeria. It also led to the entry of more Nigerian migrants from other European countries without valid visas who had not been able to travel widely for fear of being apprehended. By giving birth to an Irish child, they sought to gain freer movement within Europe by acquiring the legitimacy that residence in an E.U. country would bring. The following quote from Kómoláfé's interview with "Mrs. C.," who had moved from Lagos to Germany six years earlier, is a vivid example. Mrs. C's dilemma and her birthing strategy make a striking fit with Ireland's new law within the emerging European policies on immigration and the Schengen Agreement's free passage allowance:

I came to Ireland to have my baby and to obtain Irish residency status. I had lived in Germany for six years as an illegal immigrant. My mother died two years ago, but I was unable to go for her burial in Nigeria. I knew if I went I would not be able 
to come back to Europe. Where would I have begun again? It was a terrible experience. All I want is to be able to move from one area to another. This I am now enjoying.

So strong is the desire to bear a child on Irish soil, and hence a child who becomes an E.U. citizen, in Kómoláfé's view, that some wealthy Nigerian men even send their pregnant wives as migrants to Ireland before they themselves come. His survey of several years of Nigerian migrant history in Dublin appears to bear this out, showing that in the years following the Fajujonu case, there was a dramatic increase of female migrants of childbearing age, compared to male migrants.

Parallel to patterns of response in the other case studies I describe here, as Luibhéid (2003) shows, there are widespread allegations of manipulating this ruling against black women in Ireland, and a very recent court case involving a Nigerian woman whose claim to residence was denied suggests changes may be afoot. However, Kómoláfé's account also, in documenting post-war stages of migration by Nigerians to Ireland, points out that national authorities were leading the way to attract skilled immigrants. In recent years the country has been so desperate for skilled workers, and medical workers are probably the most sought, that Irish hospitals sometimes send recruiters to developing countries, which have trained them at great national expense, to seek out doctors and nurses very aggressively. Fajujonu himself was unemployed at the time of the court case. Still, it is tempting to posit a connection between the timing of a court decision that granted residence to the immigrant parents of Irish-born children and a time when Ireland itself, still something of a "developing country" compared to the rest of the E.U., was actively looking for ways to encourage selective immigration, as it still does. What is clear is that individuals such as Chinese entrepreneurial elites and Nigerian doctors and nurses are more likely to surmount immigration troubles than many other immigrants, who are more apt to get deported or have to settle, undocumented and vulnerable, in the less preferred nodes of international mobility circuits.

Congo-Paris age traders: The case of Congo-Paris traders mentioned earlier (MacGaffey and Bazenguissa-Ganga, 2000) is rich in descriptions of strategies surrounding citizenship. Among the most fascinating are those of the immigrants of quasi-legal (or illicit) residence status who engage in trade by maneuvering with children between the cracks of the international airline industry. Central and West Africans have reputations as traders that date back centuries (see Guyer, 2004, for a farreaching statement). They have also routinely brought children into their businesses to train them in the profession. Congo-Paris traders bring out wholly new facets of these longstanding patterns as laws and technologies change so quickly. Their strategies have 
hinged on two principal rules. First, until a few years ago, children born in France were automatically French citizens, as is still the case in the U.S. and Ireland, and like Ireland (but unlike the U.S.), their status as citizens gave the parents rights to a residence as soon as they were born. When women traders from the Congo with little or no education found that the birth of a child effectively guaranteed freedom to travel throughout Schengen countries, this made giving birth in France, with its extensive ties to francophone Africa, a natural way to start a transcontinental trading business. We see this assessment reflected in the testimony of an ambitious entrepreneur named Eloise. Lacking the legitimacy to travel to Europe early in her career, Eloise had to limit her trading to Central Africa. But she seized the opportunity that her first pregnancy presented to expand her trade and build an intercontinental trading enterprise:

[Eloise] traded between Zaire and Congo, saving up money to buy her ticket. When she became pregnant at the age of 20 , she decided that that was the moment to go to France so that her child could be born there. Afterwards she did not need a visa to enter the country. She started trading between France and Congo when her baby was eight months old. In 1994, she had been travelling [sic] back and forth for three years. She bought babies' clothes, blouses, women's sandals ... and airfreighted them to Congo-Brazzaville, where she sold them to Senegalese wholesalers or to market retailers. Sometimes she goes to Amsterdam to buy jewelry... [and resells it] in Brazzavile or Paris .... (MacGaffey and Bazenguissa-Ganga, 2000: 99).

Even more revealing are the strategies centering on children and the use of airline tickets by Congolese traders. Many Africans have sought work connected with the airline industry because of the trading advantages these positions can yield for shipping merchandise. Whereas giving birth to a child in France gave women residence rights, this allowance ended several years ago (see below) (Note 21). This legal change prompted widespread efforts to improvise on new developments in French citizenship politics. As for Congolese women traders without residence rights, many found new ways of using the practice common throughout the airline industry of giving substantial reductions in ticket prices to employees and their children under age 25. Many children who had been born when citizenship-by-birth was allowed were well under 25 , so some women who were connected with airline companies kept their trading businesses going by "adopting" child-citizens. These "children" (one adoptee was herself in her young twenties; the adopted children in another woman's account were her younger brothers) could then be dispatched on transnational trade.

What is critical to note here is that the term "adoption" that the book by MacGaffey and Bazenguissa-Ganga quotes is almost certainly a problematic translation 
of African practices, even those in France. "Fostering," while not perfect, is likely a better description of the actual domestic relationship, although better expressions are probably "minding" or simply "caring for." My speculation is that the word "adoption" is actually used in French translations, however, to appear to be meeting the qualifications for reduced ticket prices that the airlines require. African and French vocabularies begin to refract each other in subtle ways.

Polygamous Malian men in "Pasqua" Paris: Until a few years ago, as I pointed out, a child born on French soil was accorded citizenship and the parents had rights to residence. Furthermore, polygamy was tolerated. When these rights were revoked, this created enormous disruption for migrants who had based their life visions on this assumption. The account by Sargent and Cordell (2003) provides an illuminating history of this change and of the struggles of Malian families who must negotiate the quandaries of reproductive life in a society that demands legal monogamy.

After a period of flux in post-war policies, the late 1980s saw the rise of conservative Jean-Marie Le Pen and his National Front Party. Severe restrictions were placed on the immigration of spouses and the reunification of families, and polygamy was banned, while rights to citizenship and residence through a child's birth tightened sharply. Since the passage of the 1993 "Pasqua" ruling aimed for "zero-[illegal]immigration," authorities have had the right to inspect the identity papers of anyone, which they now do almost routinely at train stations marking the entry points into the country. Because a polygamous man may lose his work and residence permits for having more than one wife, many polygamous men have had to marginalize a supernumerary wife and her children by divorcing her, whether in name or in fact, or sending her back home, even though she may have originally come quite lawfully under a French regime that allowed polygamy and even though she has little in the way of security there anymore.

Another key source of hardship has arisen as well in the wake of these changes. French policies toward longstanding mainstream citizens have been decidedly pronatalist though they have sought to discourage high fertility among African immigrants. However, anecdotal evidence suggests that by exacerbating polygamous competition, policies that mandate monogamy may have led paradoxically to increased fertility among some Malian women and in dangerous ways. A wife try to bear many closely-spaced children in hopes that the man will choose her to stay in Paris as his "official" wife by virtue of her reproductive accomplishments. The strain, both economic and health, appeared to be particularly hard on the second wife, who is less likely to be designated as the "official" wife. 
"Visa" wives in Norway: This final case, actually stemming from a court case, is unavoidably "sensational." When it arose in 1997 it drew enormous national attention in Norway as well as internationally among activists and scholars concerned children, women, and immigration.

It involved a dramatic legal case of "Nadia," an 18 year old Norwegian citizen whose parents, from Morocco, were naturalized Norwegian citizens (Wikan, 2002a, 2002b). Nadia, in a phone call of distress from Morocco to a friend in Norway, claimed she had been drugged, bound, and transported overland to Morocco in a van by her own parents, who were trying to force her to marry a young Moroccan man. Neither Norway nor Morocco recognizes dual citizenship, and Morocco even stipulates that Moroccan citizenship lasts for life. Thus when Nadia was in Morocco, in which the age of legal majority is 20 and not 18 as in Norway, Morocco saw no reason to return its citizen to a foreign country, regardless of whether she was being held against her will, because she was a child, while Norway was compelled to seek the return of its adult-citizen who was pleading for help. The parents seemed to have three goals. One was to keep the family feet planted firmly in both the Moroccan homeland and in Norway's welfare state, where Nadia's father had been collecting social security benefits and a housing subsidy for a number of years for a heart problem. A second aim was to marry her to a Moroccan man of strong Muslim background who might rid her of what the parents saw as loose Norwegian morality. Finally, they sought to secure a visa to Norway for the man they had chosen for her: to make her, as Nadia put it, a piece of "merchandise." In fact, according to Wikan, in Pakistan, "...marriageable girls in Norway are called visuni - visas; and Norwegian-Moroccan girls are spoken of as gold-edged papers" (2002a: 140). The problem lay in getting Nadia to stay. Wikan's description implies that Nadia's parents aimed to make her production of a child - a child who would be a Moroccan citizen - the condition under which she would be allowed to return to Norway. Her child's Moroccan citizenship, that is, would commit her to firm Moroccan ties if she wanted to stay connected to her child. In fact, however, the national uproar that the case immediately created made Nadia's parents allow her to return after a week, and the central drama ended a year later in criminal court, with the Norwegian state prosecuting the parents for their deed (see Wikan's accounts for further details).

Running throughout Wikan's descriptions is the implication that children and their births (and there are two relevant children here, Nadia and her hypothetical Moroccan child) can be used to two ends: to gain access to Europe and to keep ties with the country of origin. Of particular note are Wikan's provocative observations on what she sees as a very paradoxical side of dual citizenship for children and women: "Dual citizenship often is presented by academics as an asset, a resource - and so it is for the likes of them.... In this, as in many matters, the crucial question is, for whom is dual citizenship an advantage? Who stands to lose and who to gain? Children, I have argued, 
may be the main losers, and girls most of all" (2002a: 140). This means as well that family reunification has an equally ugly side: “... it exposes children of immigrants in Europe, not just Norway, to immense pressure to comply with arranged marriages, and in many cases to real force" (2002a: 140).

This case, and that of the polygamous wives in Paris, reinforce other findings that the stronger the efforts by authorities to create rules that bar immigrants or clamp down on their adaptations to life in the margins, the more that dangers to children and the women who produce them may be driven underground, beneath the formal national institutions that protect and support legitimate society members.

These case studies offer compelling glimpses of life in the dynamic margins of emerging Europe. And yet it is vital to refrain from labeling them or any others simply as crass manipulations of legal loopholes. There are three principal reasons. First, for those at the social margins, the same terms that set their marginality are the ones whose vocabularies and understandings they must use as they press the edges of the new rules. Second, the social marginality that becomes so starkly visible among would-be immigrants reflects not simply greater ease in travel. It also reflects destabilization in the wider world that may undermine security in the lands they have called home (Note 22). Finally, and perhaps most important: all these cases can be traced to some cultural template in the country of origin, but tradition is a partial if not misleading explanation for the patterns they bring to light. Much of Africa still practices polygamy, especially the Sahel region that includes Mali, although many elite men in urban Africa place face pressure to maintain a monogamous appearance by marginalizing extra conjugal partners. What seems different is that in Africa, women who find themselves as marginalized "outside" wives appear to have more resources to use to make a living for themselves and their children. Being an outside wife, while less desired than being an "inside" one, is not illegal; social services (whatever their limited availability) are not limited by law to "inside" wives. And while West African women see fertility as a key to staying in the polygamous competition, pressure to produce a child every year for sustained periods would provoke community outrage (Bledsoe, 2002). People from many countries in the world still arrange marriages for their young family members. But the extraordinary cases that come to light as potential ties to the E.U. through women become so valuable seem to go far beyond local practices in Morocco; families rarely force a marriage so brutally if one or both partners are strongly opposed. Efforts to attain legitimacy emerge in paradoxical ways as people try to adapt to countries' changing rules. 


\section{Conclusion}

I have suggested that the mix of national ideologies and policies underlying fertility change on the margins of Europe is a virtually uncharted area. Who children become, the conditions under which they are born and raised, and the ties they forge among their various homelands - all matter intensely in this increasingly "globalizing" world. Trying to bear and raise children for a new state is not a magic solution, as we saw in Paris and Norway. And asylum-seeking families with small children who are caught in the limbo of refugee camps for months may find themselves deported more readily than young, single workers (Kara Murphy, personal communication, 2003). Pressures stemming from reproductive life can work against people just as easily as for them. But the possibility that children may play a different role for immigrants in marginal positions than they do for established members in the "core" points to the emphasis earlier in the paper, that the most relevant question of reproduction for immigrants is how their children may help their families in some way to attain legitimacy.

What about implications of the findings for fertility levels? How quickly, for example, will migrants' fertility change in the European context, or come to resemble that of the "home" populations? The emphasis in this paper has been elsewhere, but it is worthwhile bringing out one possibility that arises from the analysis. Most students of European demography agree that European populations are moving increasingly toward looser personal standards of reproductive legitimacy as the "second demographic transition" continues to evolve. Compared to two generations ago, there is far less emphasis now on legitimacy in the sense of staged temporalities among entry into marriage, sexuality, and reproductive life as concerns surrounding the monitored formalisms of these events continue to relax. But is this equally true for people at the immigrant margins of Europe as it is for longstanding citizens and residents? The odd thing is that standards of reproductive legitimacy among the latter seem highly stringent: those at the margins of Europe seem to operate under very strong expectations of legitimacy both in questions of births and certainly of affiliating to the state. While those securely attached to the "core" of Western Europe increasingly lapse into what in the past would have been regarded as "illegitimacy" or looser familial structures, with few apparent penalties, the opposite is expected from marginal wouldbe newcomers. This observation leads to a question. Are these two stories - efforts by immigrant families to gain legitimacy in a new state through their children, and the strikingly low and increasingly non-marital fertility in mainstream Western Europe two sides of the same coin?

I am persuaded that reproduction in developing countries is moving strongly into dynamic relationships with fertility in developed countries, though I hesitate to put the specific pieces of the puzzle together. My general speculation is that immigrant fertility 
will not assimilate to the national norms until people's status becomes more secure (Note 23). To the extent that immigrants remain marginal, that is, their fertility will be thinly related to the level in the country of immigration. One reason is that the bulk of their support must come from sources independent of those that benefit more entrenched residents. Another is that it is precisely the adaptations, if not distortions, that marginal immigrants enact because of the legal pressures they face that will make their reproductive lives different from those in the mainstream. Indeed, the harder the legal lines are drawn by the host country, the sharper the fertility differences may become. What does seem clear is that in this rapidly globalizing era, studying the dynamics of fertility in the social and legal margins of Europe is becoming essential to generating new insights into the dynamics of low fertility at the core. What is clear as well is a renewed need for reflection about the appropriate denominators in fertility analyses, especially conventional notions of national population boundaries. Just as it is no longer possible, when considering the developing world, to rest on conventional notions of reproductive practices, it is increasingly impossible to draw conclusions about the most perplexing questions of fertility in Europe and the U.S. without keeping the developing world in view. The challenges that these global denominators are beginning to pose leave the way open for culturally informed transnational demographic efforts like some of those just beginning.

\section{Acknowledgements}

Jan Hoem, together with the students and colleagues he has so generously encouraged, has helped to create a splendid base for tackling the emergence of population trends in Europe. I am especially grateful to him for his interest in the potentials of anthropology to contribute to these efforts. I am grateful as well to Gunnar Andersson and Gerda Neyer for inviting me to contribute to this volume in Jan's honor, and also to them for their help and ideas. Keith Hart, Sophie Chevalier, and Carolyn Sargent offered invaluable support and stimulating debate. 


\section{Notes}

1. For an overview of some regional patterns in family dynamics in Nordic, Western, and Southern European countries, see Lesthaeghe, this volume. For similar behavior in the U.S., see for example Goode, 1993; Bumpass, Raley, and Sweet, 1995; Goldscheider et al., 2000.

2. van Amersfoort, 1999, accuses European demographic scholarship of having an "ostrich" mentality, ignoring the phenomenon of immigration that is unfolding all around. However, in the 1990s, European population literature began to draw special attention to the labor contributions of international migration versus the competition immigrants could pose to longstanding residents and citizens, and later the potential costs and gains of raising their children. See also van de Kaa, 1993; Massey, ed., 1998; Blum, 2002; and some important new work by Lesthaeghe and his colleagues, 2000.

3. While my own focus here is on reproduction and legitimacy, Annie Phizacklea and Bridget Anderson have begun an immensely insightful project along somewhat different lines: a project entitled "Pathways to legitimacy" (Research Briefing No. 3, Transnational Communities: An ESRC Research Programme. Economic \& Social Research Council. www.transcomm.ox.ac.uk/wwwroot/phizacklea.htm, accessed Dec 28, 2003).

4. For a stark example from India, see Das, 1995; see also the collection in which it was published (Ginsburg and Rapp, eds, 1995). For works that address demographic questions more centrally, see Greenhalgh, 1995; Kertzer and Fricke, eds, 1997.

5. On family arrangements associated with these often-precarious structures, see Sargent and Cordell, 2003. And for schooling and employment patterns for youth, see Schiff (in press).

6. Such dilemma are depicted in a burgeoning genre of popular films that unveil the disturbing exploitation of undocumented immigrants both in Europe and the U.S., who cannot seek legal or medical help without risking deportation back to a brutal regime.

7. See the British Transnational Communities Programme's web site, http:www.transcomm.ox.ac.uk, for a similar observation.

8. For just a few fine examples of recent European anthropology, see Kenny and Kertzer, 1983; Esposito, 1989; Delaney, 1991; Bellier and Wilson, eds, 2000; Goody, 2000. 
9. Just recently, there has been a surge of new kinship studies. Two examples include Franklin and McKinnon, eds, 2001; Parkin, and Stone, eds, 2004. In addition, the Max Planck Institute for Social Anthropology (Patrick Heady and Chris Hahn, pers. communication) is mounting a massive study of social security in Europe through bureaucracy and kinship. There are also several engaging, and very recent, works on the politics of citizenship and reproduction. See, for example, Kahn, 2000; Kanaaneh, 2002; and (on transnational generational relations) Cole and Durham, ms.

10. The case of Africa bears parallels. Contrary to widespread images of the subcontinent as consisting of isolated collectivities frozen in time and place, African peoples before and throughout the colonial era moved along historic routes to visit kin, trade, acquire training, and seek religious and medical advice. With colonial efforts to train eager young professionals, travel routes were opened up to Europe as well.

11. For Eastern Europe, see Gal and Kligman, 2000; Verdery, 1995. For a few examples of the Mediterranean, see Kenny and Kertzer, eds, 1983, on the region in general; on Italy, see Silverman, 1975; Esposito, 1989; Kertzer and Hogan, 1989; Kertzer and Brettell, 1987; on Greece, see Friedl, 1962.

12. Where Western society has seen legitimacy as a matter of timing, a birth within a legal union, many African societies see a child's legitimacy as a function of paternal recognition and support. If the conjugal process is proceeding smoothly, a premarital birth may instead be a cause for celebration: a reflection of a young woman's fertility that hastens the union along toward a legitimate marriage.

13. There are many recent examples; e.g., Benedict Anderson, 1983; Gardner, 1995; Hannerz, 1996; Carter, 1997; Bridget Anderson, 2000; Sassen, 1998; Hansen, 2000; Haugerud et al., eds, 2000; Inda and Rosaldo, eds, 2002; Bellier and Wilson, eds, 2000; Yanagisako, 2002.

14. Such observations have led to calls for challenging forms of multi-sited ethnography (Marcus, 1995; Gupta and Ferguson, eds, 1997; Greenhouse et al., eds, 2002; Ong, 2002).

15. Massey's point (1996: 3), inspired by his extensive work on immigration to the U.S., captures the point well. Migrants, he asserts, often know the system better than the authorities simply because their lives are built on maneuvering around its rules.

16. The so-called unintended effects of policies are phenomena that Jan Hoem and his research teams have pursued with great ingenuity. For example, Hoem, Prskawetz, 
and Neyer, 2001, describe a 1990 Austrian policy that sought to improve gender imbalances by helping women re-enter the work force after a birth. Opening up a wider slice of time, however, appealed to a surprising constituency. Couples with two children who had been ambivalent about having a third child suddenly saw their balance of indecision tipped, allowing those who might otherwise have kept their child numbers at two to move on to a third child.

17. From the popular media, see Cay Johnston's description of a New York accountant for the "super-rich" ("The loophole artist", New York Times Magazine, Dec 21, 2003: 18-22).

18. For a selection of media references to the Goan case, see "Indians' Entrée to Europe is a Portuguese Passport," Chicago Tribune, June 8, 2003; and two web articles by Paulo Colaço Dias "Portuguese nationality law," http://www.geocities.com/paulocd/PortNatLaw.htm, accessed 5/13/03; "Reponse to several inaccurate articles published in the Goan Press - January and February 2004," posted 3/3/04.

19. The question of citizenship in Goa has been ambiguous for some time. In 1961, the Indian army seized the colony, although Portugal regarded it officially as a Portuguese province, and annexed it to India. Portugal at first fought the move, and later assisted in a number of legal cases of Goans who did not wish to be called Indians or "foreigners". But eventually it withdrew official objections, agreeing to cede the territory to India.

20. Citizens or residents of Portugal's former African colonies - Angola, Mozambique, Guinea Bissau, Sao Tomé, Cap Verde - also had a temporal window to enact this conversion, but this window has now closed.

21. French-born children of non-citizens can gain citizenship only at 18 and only if they have lived in France for 5 years between ages 11 and 18 .

22. According to the Italian Interior Minister, for example, Italy "reported a steep rise in illegal immigration since the September 11 [2001] terrorist attacks [on the U.S.]. The minister attributed this rise to the 'destabilizing' effects of the attack worldwide. Much of the illegal immigration is from the Middle East, mainly Egypt, Lebanon and Syria. Between January and March 2002, over 6,500 illegal immigrants have arrived, compared to 3,400 for the same period in 2001" (Migration News, http://migration.ucdavis.edu.mn, April 1, 2002).

23. A study by Andersson and Scott (2004) supports this assumption. 
Demographic Research - Special Collection 3: Article 4

-- Contemporary Research on European Fertility: Perspectives and Developments --

\section{References}

Anderson, Be., 1983. Imagined Communities: Reflections on the Origins and Spread of Nationalism. Verso, London.

Anderson, Br., 2000. Doing the Dirty Work? The Global Politics of Domestic Labour. Zed Books, London.

Andersson, G., and Scott, K., 2004. "Labour-market attachment and entry into parenthood: The experience of immigrant women in Sweden.” MPIDR Working Paper 2004. Max Planck Institute for Demographic Research, Rostock.

Barth, F. (ed.), 1969. Ethnic Groups and Boundaries: The Social Organization of Cultural Difference. Allen \& Unwin, London.

Bellier, I., and Wilson, T. (eds), 2000. An Anthropology of the European Union: Building, Imagining and Experiencing the New Europe. Berg, Oxford.

Bledsoe, C., 1990. "The politics of children: fosterage and the social management of fertility among the Mende of Sierra Leone." In: Handwerker, P. (ed.), Births and Power: The Politics of Reproduction. Westview Press, Boulder: 81-100.

Bledsoe, C., 2002. Contingent Lives: Fertility, Time, and Aging in West Africa (with contributions by Fatoumatta Banja). University of Chicago Press, Chicago.

Blum, A., 2002. "Resistance to identity categorization in France." In: Kertzer, D., and Arel, D. (eds), Census and Identity: The Politics of Race, Ethnicity, and Language in National Censuses. Cambridge University Press, Cambridge: 121147.

Bourdieu, P., 2002a. "Pierre Bourdieu on marriage strategies." Population and Development Review 28 (3): 549-558.

Bourdieu, P., 2002b. Bal des Célebataires: Crise de la Société Paysanne en Béarn. Éditions du Seuil, Paris.

Brettell, C., 1986. Men Who Migrate, Women Who Wait: Population and History in a Portuguese Parish. Princeton University Press, Princeton.

Brettell, C., 1995. We Have Already Cried Many Tears: The Stories of Three Portuguese Migrant Women. Waveland Press, Prospect Heights.

Bumpass, L., Raley, R., and Sweet, J., 1995. "The changing character of stepfamilies: Implications of cohabitation and nonmarital childbearing." Demography 32: 425-436. 
Carter, D., 1997. States of Grace: Senegalese in Italy and the New European Immigration. University of Minnesota Press, Minneapolis.

Cole, J., and Durham, D., Ms. "Introduction." In: Cole, J., and Durham, D. (eds), Age, Re-generation and the Intimate Politics of Globalization. Submitted to Indiana University Press.

Comaroff, J., and Roberts, S. (eds), 1981. Rules and Processes: The Cultural Logic of Dispute in an African Context. University of Chicago Press, Chicago.

Das, V., 2001. "National honor and practical kinship: Unwanted women and children." In: Ginsburg, F., and Rapp, R. (eds), Conceiving the New World Order: The Global Politics of Reproduction. University of California Press, Berkeley: 212233.

de Genova, N., 2002. "Migrant 'illegality' and deportability in everyday life." Annual Review of Anthropology 31: 419-447.

Delaney, C., 1991. The Seed and the Soil: Gender and Cosmology in Turkish Village Society. University of California Press, Berkeley.

Douglas, M., 1966. Purity and Danger. Routledge, London.

Esposito, N., 1989. Italian Family Structure. P. Lang, New York.

Franklin, S., and McKinnon, S. (eds), 2001. Relative Values: Reconfiguring Kinship Studies. Duke University Press, Durham.

Friedl, E., 1962. Vasilika, a Village in Modern Greece. Holt, Rinehart \& Winston, New York.

Gal, S., and Kligman, G., 2000. The Politics of Gender after Socialism: A ComparativeHistorical Essay. Princeton University Press, Princeton.

Gardner, K., 1995. Global Migrants, Local Lives: Travel and Transformation in Rural Bangladesh. Clarendon Press, Oxford.

Gilmore, D. (ed.), 1987. Honor and Shame and the Unity of the Mediterranean. American Anthropological Association, Washington D.C.

Ginsburg, F., and Rapp, R. (eds), 1995. Conceiving the New World Order: The Global Politics of Reproduction. University of California Press, Berkeley. 
Goldscheider, F., Webster, P., and Kaufman, G., 2000. "Men, parenthood, and divorce in the era of the Second Demographic Transition." In: Bledsoe, C., Lerner, S., and Guyer J. (eds), Fertility and the Male Life Cycle in the Era of Fertility Decline. Oxford University Press, Clarendon.

Goode, W., 1993. World Changes in Divorce Patterns. Yale University Press, New Haven.

Goody, J., 2000. The European Family: An Historico-Anthropological Essay. Blackwell Publishers, Oxford.

Greenhalgh, S., 1995. "Anthropology theorizes reproduction: Integrating practice, political economic, and feminist perspectives." In: Greenhalgh, S. (ed.), Situating Fertility: Anthropology and Demographic Inquiry. Cambridge University Press, Cambridge: 3-28.

Greenhouse, C., Mertz, E., and Warren, K. (eds), 2002. Ethnography in Unstable Places: Everyday Lives in Contexts of Dramatic Political Change. Duke University Press, Durham.

Gupta, A.., and Ferguson, J. (eds), 1997. Anthropological Locations: Boundaries and Grounds of a Field Science. University of California Press, Berkeley.

Guyer, J., 2004. Marginal Gains: Monetary Transactions in Atlantic Africa. University of Chicago Press, Chicago.

Hannerz, U., 1996. Transnational Connections: Culture, People, Places. Routledge, London.

Hansen, K., 2000. Salaula: The World of Secondhand Clothing and Zambia. University of Chicago Press, Chicago.

Haugerud, A., Stone, M., and Little, P. (eds), 2000. Commodities and Globalization: Anthropological Perspectives. Rowman \& Littlefield, Lanham.

Hoem, J.M., Prskawetz, A., and Neyer, G., 2001. "Autonomy or conservative adjustment: The effect of public policies and educational attainment on third births in Austria, 1975-96." Population Studies 55: 249-261.

Inda, J., and Rosaldo, R. (eds), 2002. The Anthropology of Globalization: A Reader. Blackwell, Oxford.

Kahn, S., 2000. Reproducing Jews: A Cultural Account of Assisted Conception in Israel. Duke University Press, Durham. 
Kanaaneh, R., 2002. Birthing the Nation: Strategies of Palestinian Women in Israel. University of California Press, Berkeley.

Kenny, M., and Kertzer, D. (eds), 1983. Urban Life in Mediterranean Europe: Anthropological Perspectives. University of Illinois Press, Urbana.

Kertzer, D., and Fricke, T. (eds), 1997. Anthropological Demography: Toward a New Synthesis. University of Chicago Press, Chicago.

Kertzer, D., and Brettell, C., 1987. "Advances in Italian and Iberian family history." Journal of Family History 12 (1-3): 87-121.

Kertzer, D., and Hogan, D., 1989. Family, Political Economy, and Demographic Change: The Transformation of Life in Casalecchio, Italy, 1861-1921. University of Wisconsin Press, Madison.

Kómoláfé, J., 2002. "Searching for fortune: The geographical process of Nigerian migration to Dublin, Ireland." Irinkerindo: A Journal of African Migration 1 (1). Available http://www.africamigration.com/index.html.

Laslett, P., 1980. "Introduction.” In: Laslett P. (ed.), Bastardy and Its Comparative History. Edward Arnold, Cambridge: 1-68.

Launay, R., 1995. "The power of names: Illegitimacy in a Muslim Community in Côte d'Ivoire." In: Greenhalgh, S. (ed.), Situating Fertility: Anthropology and Demographic Inquiry. Cambridge University Press, Cambridge: 108-129.

Lesthaeghe, R. (ed.), 2000. Communities and Generations: Turkish and Moroccan Populations in Belgium. Vrije University Press, Brussels.

Lesthaeghe, R., and van de Kaa, D., 1986. "Twee demografische transities?" In: Lesthaeghe, R., and van de Kaa, D. (eds), Groei of Krimp? Book volume of 'Mens en Maatschappij'. Van Loghum-Slaterus, Deventer: 9-24.

Luibhéid, E., 2003. "Globalization and sexuality: Redrawing racial and national boundaries through discourses of childbearing." In: Luibhéid, E., and Lentin, R. (eds), Women's Movement: Migrant Women Transforming Ireland. Papers from a conference in Trinity College, March 2003, Dublin.

MacGaffey, J., and Bazenguissa-Ganga, R., 2000. Congo-Paris: Transnational Traders on the Margins of the Law. London: International African Institute in association with James Currey, Oxford; Indiana University Press, Bloomington.

Marcus, G., 1995. "Ethnography in/of the world system: The emergence of multi-sited ethnography." Annual Review of Anthropology 24: 95-117. 
Massey, D., 1996. "The false legacy of the 1965 immigration act." World on the Move, Newsletter 3 (Spring): 2-4.

Massey, D. (ed.), 1998. Worlds in Motion: Understanding International Migration at the End of the Millenium. Clarendon Press, Oxford.

Neveu, C., 2000. "European citizenship, citizens of Europe and European citizens." In: Bellier, I., and Wilson, T. (eds), An Anthropology of the European Union: Building, Imagining and Experiencing the New Europe. Berg, Oxford: 119-135.

Neyer, G., forthcoming. "Towards an institutional and political approach to fertility research in Europe."

Ong, A., 2002. "The Pacific shuttle: families, citizenship, and capital circuits." In: Inda, J., and Rosaldo, R. (eds), The Anthropology of Globalization: A Reader. Blackwell, Oxford: 172-197.

Parkin, R., and Stone, L. (eds), 2004. Kinship and Family: An Anthropological Reader. Blackwell, Oxford.

Péristiany, J. (ed.), 1966. Honour and Shame: The Values of Mediterranean Society. Weidenfeld and Nicolson, London.

Said, E., 1978. Orientalism. Random House, New York.

Sargent, C., and Cordell, D., 2003. "Polygamy, disrupted reproduction, and the state: Malian migrants in Paris, France." Social Science and Medicine 56 (9): 19611972.

Sassen, S., 1998. Globalization and Its Discontents: Essays on the New Mobility of People and Money. The New Press, New York.

Scheper-Hughes, N., 1979. Saints, Scholars, and Schizophrenics: Mental Illness in Rural Ireland. University of California Press, Berkeley.

Schiff, C., In Press. "French dilemmas in the socioeconomic adaptation of immigrant and minority youth." In: Roulleau-Berger, L. (ed.), Youth and Work in the PostIndustrial City of Europe and North America. Brill, London.

Silverman, S., 1975. Three Bells of Civilization: The Life of an Italian Hill Town. Columbia University Press, New York.

Smith, R., 1956. The Negro Family in British Guiana; Family Structure and Social Status in the Villages. Routledge \& Kegan Paul, London. 
Surkyn, J., and Lesthaeghe, R., 2004. "Value orientations and the second demographic transition (SDT) in Northern, Western and Southern Europe: An update." Demographic Research, this volume.

van Amersfoort, H., 1999. "The ostrich factor in Dutch demography." In: Kuijsten, A., de Gans, H., and de Feijter, H. (eds), The Joy of Demography and Other Disciplines: Liber Americorum presented to Dirk van de Kaa on the occasion of his retirement as Professor of Demography at the University of Amsterdam. Thela Thesis, Amsterdam: 177-183.

van de Kaa, D., 1993. "European migration at the end of history." In: Blum, A., and Rallu, J.-L. (eds), European Population. Vol. 2: Demographic Dynamics. John Libbey Eurotext, Montrouge: 77-109.

Verdery, K., 1995. National Ideology under Socialism. University of California Press, Berkeley.

Wallerstein, I., 1974. The Modern World System. Academic Press, New York.

Wikan, U., 2002(a). “Citizenship on trial: Nadia's case.” In: Shweder, R., Minow, M., and Markus, H. (eds), Engaging Cultural Differences: The Multicultural Challenge in Liberal Democracies. Russell Sage Foundation, New York: 128143.

Wikan, U., 2002(b). Generous Betrayal: Politics of Culture in the New Europe. University of Chicago Press, Chicago.

Wolf, E., 1982. Europe and the People Without History. University of California Press, Berkeley.

Yanagisako, S., 2002. Producing Culture and Capital: Family Firms in Italy. Princeton University Press, Princeton. 